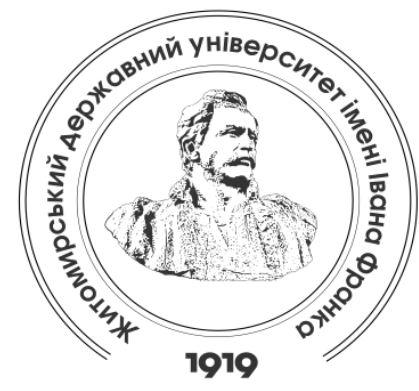

Zhytomyr Ivan Franko State University Journal. Pedagogical Sciences. Vol. 3(98)

Вісник Житомирського державного університету імені Івана Франка.

Педагогічні науки. Вип. 3(98)

ISSN (Print): 2663-6387

ISSN (Online): 2664-0155

UDC 378.091.33:004:811.111(045)

DOI 10.35433/pedagogy.3(98).2019.99-107

\title{
EXPLOITING PODCASTING TECHNOLOGY IN THE PROCESS OF ORGANIZATION OF SELF-DIRECTED LEARNING ON THE FORMATION OF FOREIGN LANGUAGE LISTENING COMPETENCE OF STUDENTS OF THE HUMANITIES
}

\begin{abstract}
O. V. Kovtun ${ }^{*}$ T. A. Harmash ${ }^{* *}$, N. I. Khaidari ${ }^{* * *}$
The article deals with the issues of implementation of innovative educational podcasting technology in the modern educational process. The advantages (the possibility of involving the student in work with authentic material, providing informal learning, formation of student's ideas about the diversity of dialects and variants of a foreign language, efficiency of use) and disadvantages (the lack of an automated system for verifying the accuracy of responses and counting the number of attempts to perform tasks and reviewing the interview, as well as a report on made mistakes and speed of tasks' accomplishment during a semester) of podcasting use in organizing self-directed learning in formation of foreign language listening competence of students of the humanities. The main methods of the research were theoretical analysis, testing, questioning, observation, conversations and educational experiment. The experience of using the "Starter BBC Interviews Video" and "BBC Interviews Extra" video podcasts from the program to the Speakout (Pearson) training series for the 1st and 2nd year students, who speak the foreign language at the initial level, as well as the Pre-Intermediate and Intermediate, and the CNN Student News podcast (3rd year) in organizing self-directed learning in listening to the discipline "Foreign Language for Specific Purpose" is described. The structure and components of the researched podcasts, as well as illustrative material in the form of printed examples of transcripts are covered. It is established that the daily use of the CNN Student News podcast within self-directed learning and on foreign language classes has improved students' listening,
\end{abstract}

\footnotetext{
* Doctor of Pedagogical Sciences, Professor

(National Aviation University)

olena-737@ukr.net

ORCID: 0000-0001-5216-6350

** Candidate of Pedagogical Sciences (PhD in Pedagogy)

(National Aviation University)

kim_ta@ukr.net

ORCID: 0000-0001-6691-4815

*** Candidate of Pedagogical Sciences (PhD in Pedagogy)

(National Aviation University)

nataliia4899@gmail.com

ORCID: 0000-0001-7283-0159
} 
speaking and writing skills, and contributed to the increase of their vocabulary. The obtained results broaden our knowledge of the role and importance of modern educational technologies in the educational process.

The conducted experimental research has proved the effectiveness of the implementation of podcasting technology in self-directed learning of students of the humanities for the formation of their foreign language listening competence, as well as the expansion of linguistic and sociocultural competence.

Key words: podcasting technology, foreign language training, foreign language communicative competence, foreign language listening competence, transcript, listening, students of the humanities, self-directed learning, innovative educational technologies, educational process.

\title{
ВИКОРИСТАННЯ ТЕХНОАОГІЇ ПОДКАСТИНГ В ПРОЦЕСІ ОРГАНІЗАЦІї САМОСТІЙНОї РОБОТИ 3 ФОРМУВАННЯ ІНШОМОВНОї АУДИТИВНОї КОМПЕТЕНЦІЇ СТУДЕНТІВ ГУМАНІТАРНИХ СПЕЦІАЯЬНОСТЕЙ
}

\author{
О. В. Ковтун, Т. А. Гармаш, Н. І. Хайдарі
}

Анотащія. У статті розкрито питання впровадження інноваційної освітньої технології подкастинг у сучасний освітній процес. Визначено переваги (можливість залучення студента до роботи з автентичним матеріалом, надання навчанню нерормального характеру, формування у студента уявлень про розмаїття діалектів $i$ варіантів іноземної мови, зручність у використанні) та недоліки (відсутність автоматизованої системи перевірки правильності відповідей та підрахунку кількості спроб виконання завдань і перегляду інтерв'ю, а також звіту помилок, шо були допущені й темпу виконання завдань протягом семестру) використання подкастингу в організаиії самостійної роботи із формування іншомовної аудитивної компетентності студентів гуманітарних спеціальностей. Основними методами дослідження стали: теоретичний аналіз, тестування, анкетування, спостереження, бесіди та навчальний експеримент. Описано досвід використання відеоподкастів "Starter BBC Interviews Video" ma "BBC Interviews Extra" з програми до навчального комплексу Speakout (Pearson) для студентів 1го і 2-го курсів, шо володіють іноземною мовою на початковому рівні, а також на рівнях Pre-Intermediate ma Intermediate, ma nодкасту новин "CNN Student News" (3-й курс) в організації самостійної роботи з аудіювання в дисиипліні "Іноземна мова (за профресійним спрямуванням)". Висвітлено структуру та компоненти досліджуваних подкастів, а також ілюстративний матеріал у вигляді друкованих прикладів транскриптів. Обтрунтовано, що шоденне використання подкасту CNN Student News в межах самостійної роботи та на заняттях з іноземної мови покращуе вміння аудіювання, говоріння та писъма студентів, сприяе збільшенню їхнього лексичного запасу. Отримані результати розширюють наші знання про роль та важливість сучасних освітніх технологій в освітньому прочесі. Проведене експериментальне дослідження довело ефективність впровадження технології подкастингу в самостійну роботу студентів гуманітарних спеиіальностей для формування їхньої іншомовної аудитивної компетениії, а також розширення лінгвосоиіокультурних знань.

\footnotetext{
Ключові слова: технологія подкастинг, іншомовна підготовка, іншомовна комунікативна компетениія, іншомовна аудитивна компетениія, транскрипт, аудіювання, студенти гуманітарних спеціальностей, самостійна робота студентів, інноваційні освітні технологіӥ, освітній прочес.
}

Introduction of the issue. National education is characterized by the search of new technologies and 100 methods of educational activity that will assist the most complete disclosure of the potential of participants of the 
educational process, the formation of skills to think freely and self-organize in the modern conditions, as well as their comprehensive development as a person and the highest value of society (the Law of Ukraine "On Higher Education", 2017). In this regard, the problem of ensuring a high-quality foreign language training of future specialists in the system of university education became urgent. Language proficiency is a practical necessity of a specialist in the modern labour market, an instrument for achieving competence and professional realization, this stipulates the necessity to improve the content and methods of foreign language training, application of innovative approaches to the formation of the foreign language communicative competence of students of the humanities, which mostly work in the system "person - person" and oriented to interlingual communication.

Standards and tendencies of the development of the European educational environment have an impact on educational processes in Ukraine, and determine the changes in sectoral curricula of higher educational establishments (HEE), which are to reduce class hours and increase the number of hours dedicated to students' self-directed learning. The growth of the role of self-study in the educational process leads to the need to change the strategy of organizing out-of-class students' activity, with the division of responsibilities for the result of studying between a teacher and a student.

In today's world a teacher of the foreign language of $\mathrm{HEE}$ faces important challenges, such as to actualize the organization of achieving the practical foreign language mastering in accordance with the updated content of programs, methods and technologies of training, to ensure the inclusion of students in a professional context, to form their skills and abilities to effectively use the Internet technologies and Internetresources for communication and selfeducation. The following documents are the regulatory framework for the application of information technologies in the educational process: the Law of Ukraine "On the National Program of Informatization" [4], the Strategy for the Development of an Information Society in Ukraine [9], and Recommendations of the Council of Europe on Language Education [3]. The above-mentioned documents provide the basis for organization of professionally oriented foreign language training of future specialists for work in the information society.

Taking into account that one of the primary goals of students' self-directed learning in the field of foreign language education is overcoming of language and communicative barriers, it is appropriate to include in the educational process the programs of indepth individual listening by students, in particular the Internet technology podcasting.

Current state of the issue. Despite of the continued interest of scientists to the problem of the usage of podcasts in the teaching of foreign languages (O. Betsko [1], T. Harmash [2], O. Zarutska [5], N. Ignatenko [6], D. Jobbings [11], J. Leach [12], G. Stanley [14], D. Warlik [15]), etc.), the problem of formation of skills and abilities of the effective use of this technology in organizing self-directed learning in listening of students of humanities in university education remains unsolved.

The outline of unresolved issues brought up in the article. The purpose of the article covers investigation of the following unresolved issues: 1) to identify pedagogical functions of podcasts in the teaching of a foreign language; 2) to determine the advantages of podcasts as a source for listening; 3) to propose ways to 
introduce the use of podcasts in foreign language classes; 4) give examples of work with English podcasts; 5) to analyse the effectiveness of podcasting technology in general, and the use of podcasts in classes of "Foreign Language for Specific Purpose", in particular.

Aim of research. Finding out the effectiveness of the practical application of podcasting technology and use of authentic podcasts in foreign language classes and during self-training of students, in particular during the study of the discipline "Foreign Language for Specific Purpose" in groups of students of the humanities of the Faculty of Linguistics and Social Communications of National Aviation University.

To reach the aim of the research, theoretical and empirical methods of scientific knowledge were used, such as: theoretical analysis, which made it possible to find out the essence of the technology of podcasting in the study of a foreign language; testing, questioning, observation, conversations that determined the importance of implementing the above-mentioned educational technology in the educational process and confirmation of its significance during the learning of a foreign language; an educational experiment that uncovered the hidden potential of innovative educational podcasting technology in formation of the audit competence of students in university education.

Results and discussion. The term "podcast" was firstly used by British journalist Ben Hammersley on February 12, 2004 in the article "The Sound Revolution" for the section "The Television Industry" of "The Guardian": ... With the benefit of the hindsight, it all seems pretty obvious. MP3 players, like Apple's iPod, in many pockets, audio production software cheap or free, and weblogging is a fixed part of the internet; all the ingredients are there for a new boom in amateur radio.
But what to call it? Audioblogging? Podcasting? GuerillaMedia? ... [8]. The word "podcast" comes from the words "iPod" (Apple MP3 player) and "broadcast" (widescreen broadcasting). There is a dual term for podcast podcasting. The term "podcasting" means the method of distributing audio or video information over the Internet [6]. Today, podcasts are understood as audio / video blogs or broadcasts transmitted in the form of releases that can be easily downloaded and listened to at any convenient time; these are individual files or a series of files that are released at the same address on the Internet and regularly updated $[1 ; 6 ; 8]$. The appropriate software for convenience of podcasts playback was developed and it regularly enters a request to the website concerning new records, on purpose to their further loading to the user's device, who, in turn, decides how and where he will use the records. Usually podcasts have a certain theme and periodicity of the release [1].

The scope of the possibilities of this technology is widely disclosed in the process of foreign language learning, since the use of podcasts promotes not only the formation of listening skills and the ability to perceive different speech styles with different accents and intonations, improving the skills of speaking, but also increasing the motivation to learn a foreign language due to the ability to process a diverse and current audio material. What makes the use of educational podcasts so effective for the development of listening skills? Generalization of the views of scientists $[5 ; 6 ; 7 ; 14]$ on this issue makes it possible to determine a number of advantages of using this technology in organizing students' selfdirected learning in listening:

- the ability to involve a student to work with authentic material, giving an informal character to the training process, that is not limited by the class; 
- the offered audio material in podcasts can be downloaded and repeatedly used for foreign language classes in combination with other tasks;

- students are given the opportunity to listen to the speakers and get used to authentic speech;

- podcasts are convenient because there is no need to regularly check the site in search of updates, because due to subscription to the channel, the program automatically sends notifications for downloading new material;

- podcasts are sorted by themes, so repeated listening to different texts on an interesting topic contributes to a deep and conscious understanding of the language being studied;

- podcasts give students an idea of the diversity of dialects and variants of a foreign language, which will further help to avoid cultural shock;

- technology requires a gradual change of topics, which ensures the expansion of linguistic and sociocultural competence in general.

It should be noted, that in order to form and improve the listening skills of students, it is necessary to use various training audio podcasts.

The practical experience of using Pearson podcast https://www.english.com/speakout/ can serve as an example of introducing podcasting technology in the organization students' self-directed learning.

Practice took place in groups of students of non-language students of the humanities of the Faculty of Linguistics and Social Communications of National Aviation University.

The first year students were offered educational materials of the initial block "Starter BBC Interviews Video" for students' self-directed learning in listening. The block consists of generallinguistic video interview (General English), so even students with a low level of foreign language skills did not have the difficulty with self-directed processing of audio/video materials. Video interviews were taken off by the BBC for educational purposes, so the speed of speech and pronunciation are clear, themes are easily understood without special context-based training.

The second year students of the humanities were offered the video of the block "BBC Interviews Extra" levels of Pre-Intermediate (themes: Life, Work, Time Out, Great Minds, Travel, Fitness, Changes, Money, Nature, Society, Technology, and Fame) and Intermediate: Identity, Tales, Contact, Jobs, Solutions, Emotion, Success, Communities, History, World) from the appendix of the Speakout 2nd Edition series. Videos are given in the form of interviews with six real people (not speakers) in each episode, so students have an opportunity to hear the modern English language of ordinary people, as well as different pronunciation. The duration of the video at the PreIntermediate level is from 1:02 to $2: 01$ minutes and at the Intermediate level from $1: 21$ to $2: 12$ minutes. The video is accompanied by educational tasks (7-8 tasks) on the understanding of oral speech, as well as exercises on vocabulary and personalization, when students are asked to answer the interviewer's questions (in writing); additionally are mentioned references to thematic article from the BBC website.

Among the main advantages of this resource should be distinguished the uniformity and systematic materials release; the availability of video files in open access to students and teachers at Pearson publisher's website (www.pearsonelt.com), tasks to video podcasts are available to HEE lecturers in the Speakout Extra Resourses section in .pdf format after registration.

Among the disadvantages the following are distinguished: the lack of an automated system for verifying the accuracy of responses and counting the 
number of attempts to perform tasks and reviewing the interview, as well as a report on made mistakes and speed of tasks' accomplishment during a semester.

The third year students of the humanities were offered podcasts of CNN Student News - a 10-minute daily news program. The program is broadcasted from Monday to Friday each week during the academic year and is available online as well as in the form of a podcast. It can be easily downloaded to watch and listen at any convenient time. The program has a clear structure and contains the following components:

1) an introduction and the final speech of the anchorman of the program Carl Azuz, whose speech is full of phraseological authentic units, metaphorical and slang statements, such as,

Hi I'm Carl Azuz. On last Thursday show at CNN 10.com we reported on some of the reasons for a worsening crisis in Venezuela. Today on CNN 10 we're looking at some of the effects it's having on the South American Nation. Countries around the world are taking sides and what's happening here. After a Venezuelan lawmaker named Juan Guido declared himself to be the new temporary leader of his country the U.S. said it would support him. A growing number of other countries like Argentina, Australia, Brazil, Britain, Canada and Chile have done the same thing. Additional European leaders have said they'd also support Guido if Venezuelan president Nicolas Maduro doesn't schedule free elections soon. But president Maduro said nobody gives Venezuela and ultimatum and that his country had held elections which he says he won. He accuses the U.S. of setting up a coup to remove him from power in China, Cuba and Russia are among the countries who put their support behind Maduro. Yesterday the United States announced new sanctions or penalties on the South American country to increase the pressure on its embattled leader. Some Venezuelans have rallied behind president Maduro but many others have protested against him and more demonstrations are scheduled this week the people caught in the middle are suffering (Aired January 29, 2019);

2) three or four reports on the events of the political, international, social and cultural life of the United States of America - with interviews of people from different social groups, geographic regions, both the United States and other countries;

3) different types of questions to the audience, which precede the broadcast of the next news and acquaint listener with further informational message:

a) multiple choice questions (Shoutout questions), for example: - But is that progress the arrangement of the second summit or is the progress actual compromise on this issue of the timeline of denuclearization and the lifting of sanctions? (Aired January 23, 2019);

b) true/false questions, for example: - Ten second trivia. Which of these places is located in the Irish Sea? The Bay of Biscay, Aran Islands, Inner Hebrides, or Isle of Man? The only one of these places located directly between England and Ireland is the Isle of Man. (Aired November 14, 2018);

c) questions that can be posted on a blog site, - according to the opinion of the audience concerning the events being discussed. For example, what rhymes with do-mini-utive? (Aired November 14, 2018);

4) information reports on a historical event or explanation of the nationally biased units. For example, before the parliamentary elections, explanations of the political parties' names and the history of their occurrence were given.

The advantage of this resource is also that a full set of materials to the daily program is offered on the podcast website 
http://edition.cnn.com/studentnews/i ndex.html, such as transcripts for each broadcast of the program, analytical issues to discuss each program and questions to check the retained knowledge according to events, broadcasted during the week, geographic maps that can be downloaded in PDF format and references to similar articles and video reports from the CNN news website. On the website where the podcast is available, there are also references to articles on the discussed topics, which can be re-read at home as homework for further discussion of the topic.

As part of the study, using a list of analytical questions for discussion and a print out of the program that are daily updated on the podcast website, we were able to conduct an extended group discussion of the broadcast of separate events relevant throughout the society (for example, massacres of students in US schools, natural disasters, etc.) or those that coincide with the main topic of the lesson (education, social life, environmental problems, etc.). In addition, students were involved to participation in the discussion of events and issues on the blog's website. Among the offered tasks there was writing of different essays according to the topics highlighted in the program (for example, after watching the news about the earthquake and tsunami in Indonesia (Aired October 1, 2018), the students were asked to write an appeal letter on behalf of the victims according to restitution of the disaster, in the format required by the basic course textbook).

Conclusions and research perspectives. The participation of lecturers and students in the experiment on the implementation of podcasting technology in classroom and self-study in the educational process revealed the focus of the latter on the development of listening skills, ensured better understanding of native speakers and improved pronunciation.

Another positive use of such innovative educational technology as podcasting became that students of the humanities began to better orient themselves in the current political, economic and cultural life of the country, language of which they study. As a result of regular work with podcasts, participants of the experiment mastered a large number of nationally biased units, found out a lot of well-known people in the Englishspeaking world and learned to recognize them both by speech and appearance.

As our observations have shown, the daily use of the CNN Student News podcast within self-directed learning and on foreign language classes has improved students' listening, speaking and writing skills, and contributed to the increase of their vocabulary. The lessons became more interesting and less formal, and the scope of topics for discussion was considerably expanded. Thus, the implementation of innovative technologies and the application of modern methods, means and forms of studying has a positive impact on the educational process of foreign language mastering.

Further research on the topic should be aimed at expanding the audio and visual base, improving the control function of performing tasks and involving students of language specialties in the experiment. Prospects for further scientific research consist in the search for new educational technologies to improve the foreign language training of consumers of educational services in higher education.

\section{REFERENCES (TRANSLATED \& TRANSLITERATED)}

1. Betsko, O.S. (2012). Dydactychni ta metodychni zasady integratsii podkastiv $\mathrm{v}$ protses navchannia inozemnoi movy $u$ vushchiy shkoli 
[Didactic and methodical principles of integrating podcasts into the process of teaching a foreign language at a higher school]. Novitni osvitni tekhnologii - The latest educational technologies. Kyiv. Retrieved from http://confesp.fl.kpi.ua/node/1074 [in Ukrainian].

2. Harmash, T.A. (2018). Virtualnyi informatsiinyi prostir $\mathrm{V}$ organizatsii samostiynoi roboty studentiv $u$ vuvchenni inozemnoi movy [Virtual informational environment in the organization of students' self-directed learning in foreign language studying]. Podolannia movnykh I komunikatyvnykh barieiv: osvita, nauka, kultura-Overcoming of linguistic and communicative barriers: education, science, culture. Kyiv, 68-71 [in Ukrainian].

3. Zahalnoyeuropeiski

Rekomendatsii $z$ movnoi osvity: vyvchennia, vykladannia, otsinyvannia [European Recommendations on Language Education: Learning, Teaching, Evaluating]. Retrieved from https://web.archive.org/web/2013080 1023124/http://www.britishcouncil.or $\mathrm{g} / \mathrm{uk} /$ ukraine-education-reformeuropean-framework-re_vstup.pdf [in Ukrainian].

4. Zakon Ukrainy "Pro Natsionalnu programu informatzatsii" [The Law of Ukraine "On the National Program of Informatization"]. Retrieved from http:/ / zakon4.rada. gov.ua/laws/show/74/98 Ukrainian].

5. Zarutskaya, Ye.V. Podkastu Internet-resursa All Ears English v obuchenii interaktivnoi storone ustnogo obshchenia na angliiskom iazyke studentov urovnia B2-C1 [Podcasts of the Internet resource All Ears English in teaching the interactive side of oral communication in English of students of the level B2-C1]. Pedagogika. Voprosy teorii $i$ praktiki - Pedagogy. Issues of theory and Practice. Tambov, vol .4, ed. 1 , 25-28. DOI: https://doi.org/10.30853/pedago gy.2019.1.5. [in Russian].

6. Ignatenko, N.A. (2016). Podkasty angloyazychnogo radio $\mathrm{v}$ samostoyatelnoi rabote studentov na prodvinytom etape obuchenia innostrannomu yazyku [The podcasts of the English-language radio in the students' self-directed learning at an advanced level of foreign language learningl. Yazyk $i$ kultura - Language and culture, 1 (33), 148-159. DOI $10.17223 / 19996195 / 33 / 12$. [in Russian].

7. Kotsyuk, L.M. (2013). Pro dosvid integratsii avtentychnogo podkastu CNN Student News $u$ ziniattia $z$ angliiskoi movy dlia studentiv-filologiv [On the experience of integrating the CNN Student News genuine podcast into English language classes for philology students]. Naukovui blog Scientific blog. Retrieved from https://naub.oa.edu.ua/2013/prodosvid-intehratsiji-avtentychnohopodkastu-cnn-student-news-uzanyattya-z-anhlijskoji-movy-dlyastudentiv-filolohiv/ [in Ukrainian].

8. Podkastung-Podcasting.

Retrieved from https://ru.wikipedia.org/wiki/Подкаст инг[in Russian].

9. Strategia rozvytku informatsiynogo suspilstva $v$ Ukraini [Strategy for the development of an information society in Ukraine]. Retrieved from https://zakon0.rada.gov.ua/laws/show Lru/386-2013-\%D1\%80/paran8\#n8 [in Ukrainian].

10. CNN Students News. Retrieved from

http://edition.cnn.com/studentnews/i ndex.html [in English].

11. Jobbings, D. (2005). Exploiting the educational potential of podcasting. Retrieved from http://www.recap.ltd.uk/articles/podg uide.html [in English]. 
12. Leach, J. (2006). Podcasting for schools: The basics. Retrieved from http://education.guardian.co.uk/apple education/story/0,,1682639,00.html [in English].

13. McCaughey, K. (2015). Practical Tips for Increasing Listening Practice Time. Forum Magazine, 2, 2-12. [in English].
14. Stanley, G. (2006). Podcasting: Audio on the Internet comes of age. TESL-EJ, 9(4). Retrieved from http:/ / www writing.berkeley.edu/TESLEJ/ej36/int.html [in English].

15. Warlick, D. (2005). Podcasting. Technology \& Learning, 26(2), 70.

Received: June 14, 2019 Accepted: August 29, 2019 